\title{
Original Paper \\ Prior fertilization enables higher survival of relocated terricolous orchids?
}

\author{
Rogério Mamoru Suzuki ${ }^{1,5,14}$, Vivian Tamaki ${ }^{2,6}$, Catarina Carvalho Nievola ${ }^{2,7}$, Janaina Pinheiro Costa ${ }^{3}$, \\ Marina Crestana Guardia ${ }^{4,8}$, Monica Valéria Cachenco ${ }^{4,9}$, Shoey Kanashiro ${ }^{2,10}$, Waldyr Baptista ${ }^{4,11}$, \\ Yoshito Shidomi ${ }^{1,12}$ \& Nelson Augusto dos Santos Junior ${ }^{4,13}$
}

\begin{abstract}
The construction of highways causes several impacts on the environment, including, the suppression of vegetation, which can lead to reduced biodiversity. One mitigating measure involves reallocating plant to protected areas and orchids might be important for this use. An example could be the terricolous orchid Sauroglossum nitidum. In an attempt to optimize the survival of S. nitidum following reallocation, the aim of this study was to investigate whether the fertilization can increase the survival of this orchid. For this, five lots with ten plants per lot were randomly separated, with five plants submitted to soluble fertilization with NPK 10-52-10 $\left(1\right.$ g.L $\left.\mathrm{L}^{-1}\right)$, spraying each plant with $1 \mathrm{~mL}$ of the fertilizer, and the other five sprayed with the same volume of distilled water. This treatment was repeated fortnightly for two months before reallocation. The plants were relocated in September 2015 and monitored monthly until November 2016. Overall orchid survival was $92 \%$. Additionally, flowering was observed to be significantly higher in fertilized plants. In conclusion, reallocation of $S$. nitidum with previous NPK fertilization is recommended.
\end{abstract}

Key words: compensatory measures, Orchidaceae, Sauroglossum nitidum.

\section{Resumo}

A construção de rodovias causa diversos impactos no meio ambiente, incluindo a supressão da vegetação, que pode levar à redução da biodiversidade. Uma das possíveis medidas mitigadoras envolveria a realocação de plantas resgatadas para áreas protegidas e as orquídeas seriam uma das que possuem particular importância. Dentre as orquídeas, um exemplo poderia ser a espécie terrícola Sauroglossum nitidum. Visando otimizar a sobrevivência de $S$. nitidum após a realocação, o objetivo foi investigar se a fertilização aumentaria a sobrevivência desta orquídea. Para isso, foram separadas aleatoriamente cinco grupos contendo dez plantas, sendo cinco plantas submetidas à adubação foliar com NPK 10-52-10 (1 g.L $\left.{ }^{-1}\right)$, pulverizando cada planta com $1 \mathrm{~mL}$ do fertilizante e as outras cinco pulverizadas apenas com o mesmo volume de água destilada. Este tratamento foi repetido quinzenalmente por dois meses antes da realocação. As plantas foram realocadas em setembro de 2015 e monitoradas mensalmente até novembro de 2016. A sobrevivência das orquídeas foi de $92 \%$. Além disso, observou-se que a floração foi significativamente maior em plantas fertilizadas. Em conclusão, recomenda-se a realocação de $S$. nitidum com prévia fertilização com NPK.

Palavras-chave: medidas compensatórias, Orchidaceae, Sauroglossum nitidum.

\footnotetext{
${ }^{1}$ Instituto de Botânica, Núcleo de Pesquisa - Orquidário do Estado, São Paulo, SP, Brazil.

${ }^{2}$ Instituto de Botânica, Núcleo de Pesquisa em Plantas Ornamentais, São Paulo, SP, Brazil.

${ }^{3}$ Instituto de Botânica, Núcleo de Pesquisa Reserva Biológica do Alto da Serra de Paranapiacaba e Parque Estadual das Fontes do Ipiranga, São Paulo, SP, Brazil. ORCID: <https://orcid.org/0000-0001-5749-2753>.

${ }^{4}$ Instituto de Botânica, Núcleo de Pesquisa em Sementes, São Paulo, SP, Brazil.

${ }^{5}$ ORCID: <https://orcid.org/0000-0003-1124-9875>. ${ }^{6}$ ORCID: <https://orcid.org/0000-0003-1426-9775>. ${ }^{7}$ ORCID: <https://orcid.org/0000-0003-0627-1357>.

${ }^{8}$ ORCID: <https://orcid.org/0000-0002-8676-8648>. ${ }^{9}$ ORCID: $<$ https://orcid.org/0000-0003-4696-545X>. ${ }^{10}$ ORCID: $<$ https://orcid.org/0000-0003-0118-1723>.

${ }^{11}$ ORCID: <https://orcid.org/0000-0002-8184-9350>. ${ }^{12}$ ORCID: <https://orcid.org/0000-0001-6098-4214>. ${ }^{13}$ ORCID: <https://orcid.org/0000-0002-9601-2350>.

${ }^{14}$ Author for correspondence: rsuzuki@ibot.sp.gov.br
} 


\section{Introduction}

São Paulo, Brazil, is the 10th richest city on the planet and, in 2015, the population was estimated at more than 12 million, with more than 7.5 million vehicles. As a consequence, traffic has become a problem in Brazil's largest city (Cintra 2014). In 1998, in an attempt to relieve oversaturated traffic on the main avenues of the capital, the state government of São Paulo initiated the construction of the "Rodoanel Mário Covas" (a new highway around the periphery of the city). This highway encircles the city and covers 176.5 $\mathrm{km}$, functioning as a hub linking the city of São Paulo to other localities within in the state and throughout the country.

The Northern segment was the final section of the "Rodoanel Mario Covas" construction, and will have $47.6 \mathrm{~km}$ of extension. Despite the obvious benefits of this construction project, this highway crosses an extensive area of forest, inside the "Parque Estadual da Cantareira" (PEC). Created in 1962, the PEC spans 7,916.52 ha (Dantas 1990), is considered one of the largest urban forests in the world, representing one of the main forests remaining in the metropolitan region of São Paulo city. Among the impacts from the highway construction is native vegetation suppression, and subsequent reductions in local biodiversity. In an effort to mitigate potential alterations related to biodiversity, some types of plants, like orchids for example, have been removed from their native habitats and reallocated to protected areas (Jasper et al. 2005).

Orchids, due to their restricted occurrence, represent an important herbaceous plant component of the habitat, that are generally in preserved in forested areas. In nature, infrequent seed germination and reduced longevity, represent additional problems with orchid propagation (Suzuki et al. 2012). The maintenance of these species within their natural ecosystem is important, given that orchids are excellent indicators of environmental quality (Dorneles \& Trevelin 2011). Therefore, studies on the reallocation of orchids are very rare in the literature.

A relatively great number of Sauroglossum nitidum (Vell.) Schltr. were rescued from forestsuppressed areas inside the PEC, enabling us to study reallocation procedures, within the PEC for this species. S. nitidum is a terricolous orchid. In South America, it has been found to occur in mountainous areas of Andes, from Colombia to Chile and Argentina; in Brazil, in the states of
Bahia, Goiás, Espírito Santo, Minas Gerais, Rio de Janeiro, São Paulo, Paraná, Santa Catarina and Rio Grande do Sul. These plants usually grow within forests, in slightly lighter areas, blooming predominantly in the winter (Romanini \& Barros 2007).

Large-scale orchid growers use soluble fertilization to optimize growth, either leaf or root (Campos 1998), mainly with the use of fertilization (Bernardi et al. 2004). The fertilized treatment with $75 \%$ weekly Sarruge solution provides good vegetative development of Dendrobium nobile plants, being indicated for the optimization of commercial scale production of this species. Orchid fertilization based solely on different NPK formulations are the most commonly used by commercial producers (Campos 1998; Monda et al. 2014; Ali et al. 2014). A previous study showed that phosphorus is involved in root formation and that plants grown in the presence of high concentrations of this nutrient presented higher auxin concentrations in the apical root meristems and higher cellular mitotic activity (López-Bucio et al. 2003). Additionally, the roots of orchids have evolved highly specialized functions, that maintain diversity and plasticity in root architecture, which may significantly contribute to the ability of the plant to cope with diverse environmental stimuli (Du \& Scheres 2018). In an attempt to optimize the survival of $S$. nitidum following reallocation, the aim of the present study was to investigate whether NPK fertilization could improve the outcome for this terricolous plant.

\section{Material and Methods}

\section{Study area}

The area used for the reallocation of orchids was located in the "Parque Estadual da Cantareira" (PEC), at the "Núcleo do Engordador", which belongs to the Instituto Florestal of the State of São Paulo's Environmental Department, with coordinates $23^{\circ} 24^{\prime} 37^{\prime \prime} \mathrm{S}$ and $46^{\circ} 35^{\prime} 25^{\prime \prime} \mathrm{W}$. The photosynthetic photon flux density measured in this location varied from 11 to $21 \mu \mathrm{mol} . \mathrm{m}^{-2} \cdot \mathrm{s}^{-1}$. The orchids were planted about $50 \mathrm{~cm}$ from one another.

Based on the Köppen climate classification system this region is classified as Cwa mesothermic and humid, with rainy summers and dry winters (Koppen \& Geiger 1928). January and February are typically warmer months, while June and July are cooler. Although the average temperature in the PEC is $19.9{ }^{\circ} \mathrm{C}$, absolute maximum 
temperatures exceeded $34^{\circ} \mathrm{C}$, in January, October and December. According to the Management Plan of the Conservation Unit, from 1992 to 2007, the average annual rainfall was $1,322 \mathrm{~mm}$, with the highest rainfall occurring during the period of January to March (São Paulo 2009).

The main forest component of the PEC is Ombrophilous Dense Mountain Forest, and is currently in several stages of regeneration. It originated from the end of the $19^{\text {th }}$ century, from the regeneration of areas that were acquired supplying water to the city of São Paulo. Most of the forest is in the middle stage of regeneration, but there are also a few significant stretches in advanced and mature stages. The latter areas are closer to their original forest, thus providing matrices for restocking (São Paulo 2009).

\section{Study material and description of experiments}

Sauroglossum nitidum (Vell.) Schltr. plants rescued from the deforestation area, were cultivated in substrate taken from their original area. For one year the plants were maintained in a shade nursery until reallocation. On hot days water was provided daily, and every 2 or 3 days on colder and/or cloudy days. Of the plants that survived this initial transfer period, $50 \mathrm{~S}$. nitidum plants, of similar size and leaf number were selected. These plants were divided into ten groups, containing five plants each. Five of these groups were subjected to soluble fertilization by spraying each plant with about $1 \mathrm{~mL}$ of $1 \mathrm{~g} . \mathrm{L}^{-1}$ of Nitrogen-Phosphorus-Potassium (NPK) 10-52-10, a concentration widely used by nursery owners. The other groups were sprayed with the same volume of distilled water. Both treatments were performed fortnightly, during the two months prior to reallocation.

Before reallocation, the number of leaves were counted, and leaf chlorophyll was determined using a Minolta SPAD-502. The plants were transferred in September 2015 and analyzed monthly until November 2016. During these 15 months, measurements such as: survival, number of leaves, sprouting, flowering and leaf chlorophyll were recorded.

The monthly accumulated rainfall, as well as the mean, minimum and maximum temperatures, during this work, at PEC, are presented in Figure 1. It should be pointed out that two months before the orchids were to be reallocated, the accumulated

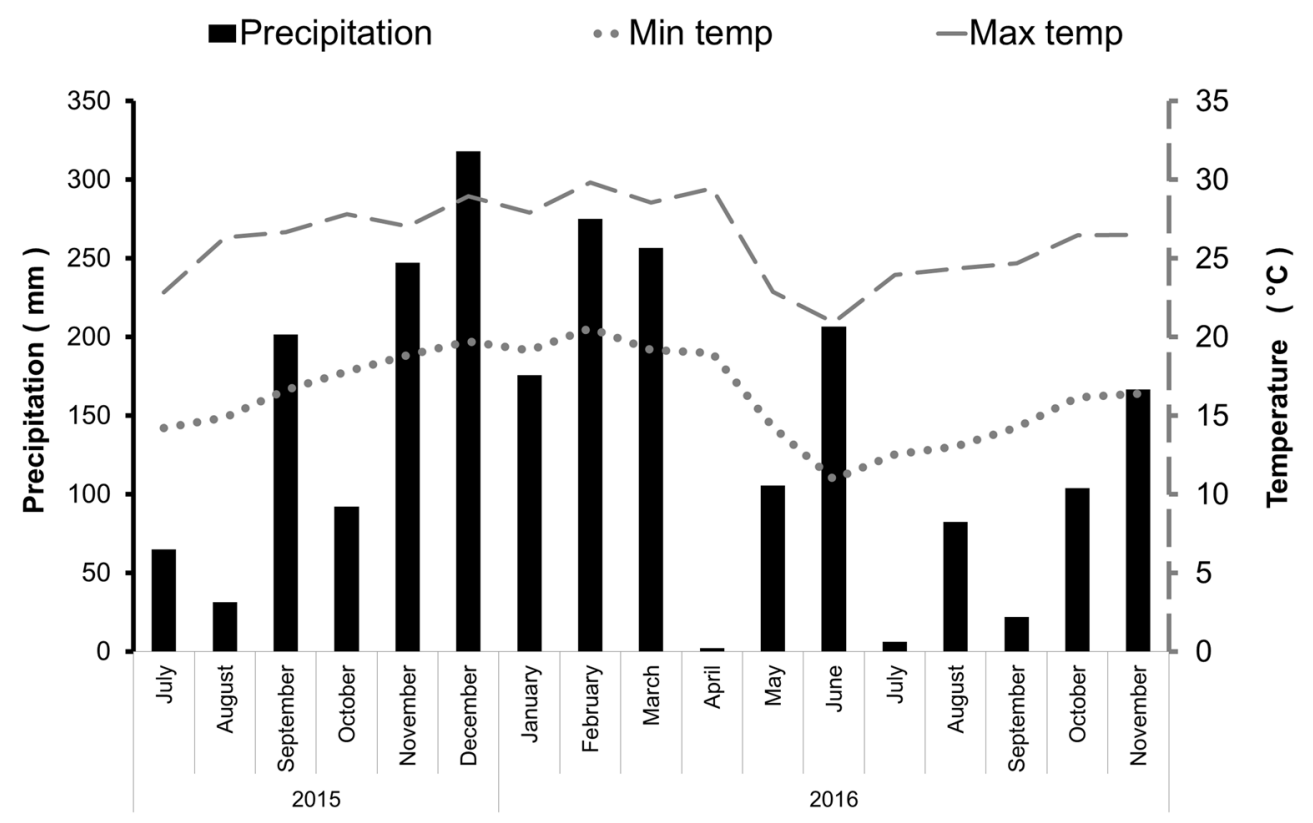

Figure 1 - Average monthly accumulated precipitation, and minimum and maximum temperature in the Santana observatory in São Paulo, SP. Data was obtained from National Meteorology Institute (INMET), using the Meteorological Database for Teaching and Research (BDMEP) two months before monitoring the reintroduced Sauroglossum nitidum. 
precipitation was $96.7 \mathrm{~mm}$, and in the month of reallocation it rained $201.7 \mathrm{~mm}$. During the 15 months monitoring period, monthly precipitation varied from 2.4 to $318.1 \mathrm{~mm}$. More specifically, there were 2.4 and $6.4 \mathrm{~mm}$ of accumulated rainfall in April and July of 2016, respectively, and 318.1 and $275.1 \mathrm{~mm}$ in December of 2015 and February of 2016, respectively. The lowest temperature was observed in June $2016\left(11^{\circ} \mathrm{C}\right)$ and the highest occurred in February $2016\left(30^{\circ} \mathrm{C}\right)$.

\section{Pigment analysis}

Photosynthetic pigments were extracted using a protocol adapted from Munné-Bosch \& Lalueza (2007) and the concentrations were calculated according to Lichtenthaler (1987). Absorbance was measured in a spectrophotometer (model PG Instruments - T60), using glass cuvettes. Chlorophyll $a(\mathrm{C} a)$ concentrations were based on absorbance (A) at $662 \mathrm{~nm}$, chlorophyll $b(\mathrm{Cb})$ concentrations were based on A at $645 \mathrm{~nm}$ and carotenoid $(\mathrm{C})$ concentrations were based on $A$ at $470 \mathrm{~nm}$. The following equations were used to determine the concentrations:

$$
\begin{aligned}
& \mathrm{C} a=11,24 \text { A } 662-2,04 \text { A } 645 \\
& \mathrm{C} b=20,13 \text { A } 645-4,19 \text { A } 662 \\
& \mathrm{C}=(1000 \text { A } 470-1,90 \text { C } a-63,14 \text { Cb }) / 214
\end{aligned}
$$

Chlorophyll and carotenoid tissue content were expressed in $\mu \mathrm{g}$ of pigment per gram of fresh mass $\left(\mu \mathrm{g} \cdot \mathrm{g} \mathrm{FM}^{-1}\right)$.

\section{Data analysis}

The experimental design was completely randomized (CDR) in the reallocation site. For each treatment, five replicates were performed, with $\mathrm{n}=5$ for each replicate.

For each parameter averages and standard deviations were analyzed using ANOVA, and comparisons were made with the Tukey test at a $5 \%$ probability level.

Correlation of $S$. nitidum photosynthetic pigment concentrations were performed according to Markwell et al. (1995).

\section{Results}

As shown in Figure 2a, the rescued plants displayed a high survival percentage, with $92 \%$ of plants, and no detectable difference between the fertilized and non-fertilized groups, remaining alive 15 months after transplantation.

The number of leaves in reallocated plants treated with fertilizer was higher in most of months and significantly dec 2015 until april 2016 (Fig. $2 b$ ). In fact, the average number of leaves on the fertilized plants was higher every month following reallocation (since October 2015). The greatest difference in the number of leaves occurred in March 2016, when the fertilized plants had an average of four leaves per plants versus three for the unfertilized plants. As expected, the smallest difference between fertilized and unfertilized plants occurred in the month following reallocation (October 2015), when fertilized and unfertilized plants presented 3.6 and 3.5 leaves per plant, respectively. The overall average did not show a significant difference for fertilization. Analyzing the number of leaves of the fertilized and unfertilized plants in the months, could observe that only in the fertilized ones did the number of initial leaves resume the T0, verified in March and November 2016. In the unfertilized plants the number of leaves never reached the initial value before the relocation.

With regards to photosynthetic pigments, there was not a significant difference of chlorophyll $a$ in unfertilized plants compared to fertilized plants (Fig. 3a). Less amount of chlorophyll $b$ was observed in fertilized plants than in non-fertilized plants, significantly difference from dec 2015 to mar 2016. Monthly analyzes in each treatment show a higher amount in Aug 2016 and feb 2016, fertilized and unfertilized plants, respectively (Fig. 3b). Regarding carotenoids there was not a significant difference between treatments and monthly in each treatment (Fig. 3c).

Figure 4 a shows that, in both fertilized and non-fertilized plants, the emergence of buds five months after the reallocation, and that after 15 months $28 \%$ and $32 \%$ of the fertilized and unfertilized exhibited buds. In addition, Figure 4a indicates a progressive development of the transplanted plants, since there was a tendency for the percentage of plants with buds to increase during the experiment.

As shown in Figure 4b, fertilization had a significant effect on flowering. For example, nine months after reallocation, $28 \%$ of the fertilized plants and only $12 \%$ of the unfertilized plants presented inflorescences, and lasted 4 months (Fig. 4b).

The steps involved in $S$. nitidum reallocation are presented in Figure 5. Figures 5a and 5b show images of fertilized and unfertilized plants, respectively, just before reallocation. Images of the plants three months after reallocation are 
shown in Figure $5 \mathrm{c}$, fertilized plants with lateral bud development are presented in Figure 5d. The initial emergence of a flower stem was observed in June 2016 is displayed in Figure 5e, and plants with flower stalk and close of inflorescences are provided in Figures $5 \mathrm{f}$ and $5 \mathrm{~g}$, respectively. The inflorescence appears to exceed $50 \mathrm{~cm}$. The $2 \mathrm{~cm}$ flowers have green petals and sepals, and with a white lip. Floral senescence caused the petals and sepals to become yellowish. Fruit formation is depicted in Figure 5h, and occurred about a month before the dehiscence of wind dispersed seeds.

\section{Discussion}

The percent survival (92\%) demonstrated in the present study with $S$. nitidum is among the highest reported for orchid reallocation projects. For example, studies by Dorneles \& Trevelin (2011) and that of Endres Jr. et al. (2015) and Endres Jr. et al. (2018) reported survival percentages of 83, 60 and $68 \%$, respectively, when investigating Cattleya reallocation. Seeni \& Latha (2000) achieved $70-80 \%$ survival with Vanda coerulea Griff., following forest reallocation. Moreover, Yam et al. (2010) demonstrated high survival rates following
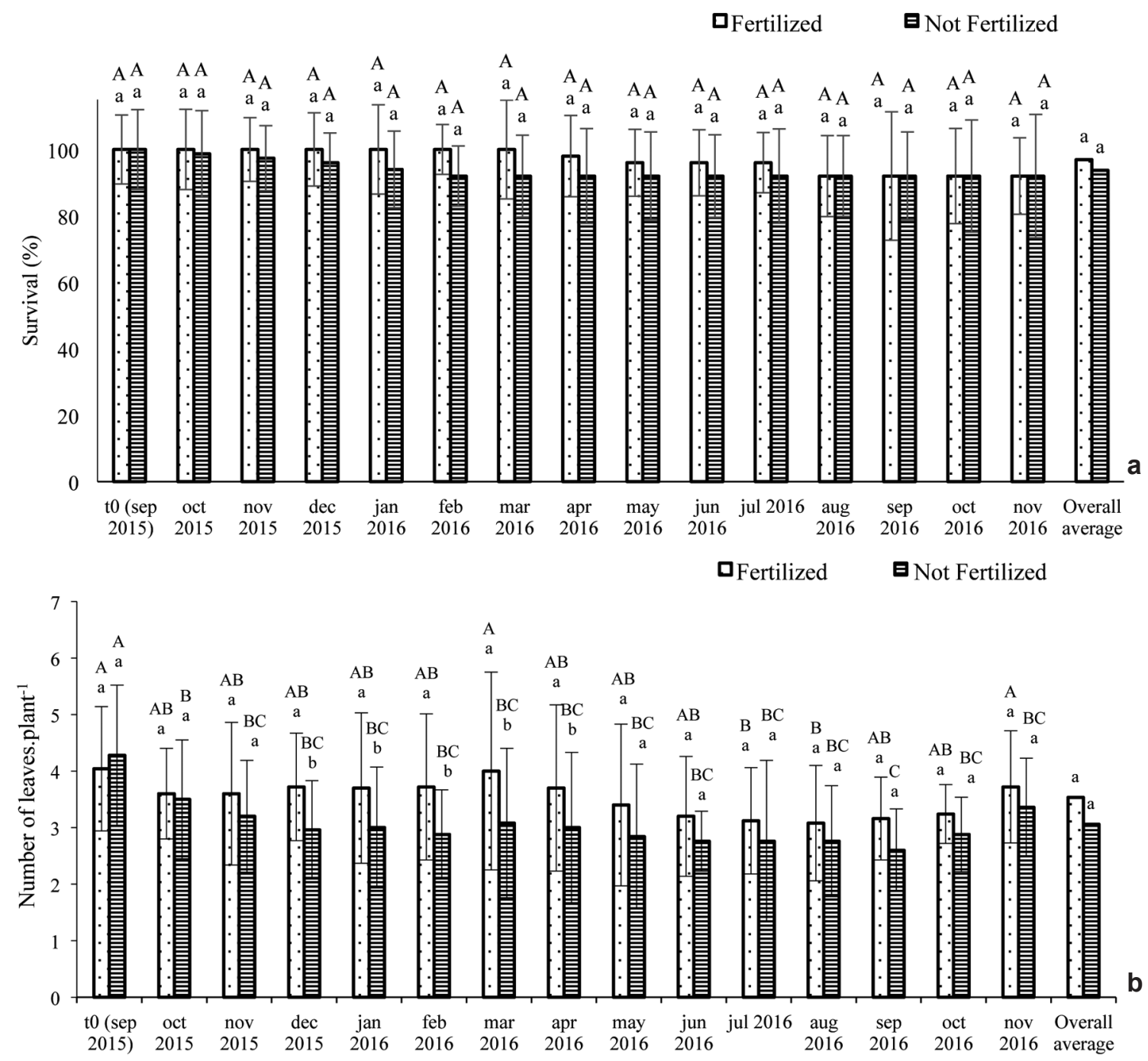

Figure 2 - Monthly values for (a) percent survival and (b) average number of leaves per Sauroglossum nitidum plants reallocated in the Parque Estadual da Cantareira, São Paulo, Brazil. The mean values with the same letter are not different by the Tukey test. Lower case letters compare fertilized and unfertilized plants each month and upper case letters compare months in each treatment. $\mathrm{n}=50$. 
reintroduction with Bulbophyllum vaginatum Rchb.f. (90\%), Bulbophyllum membranaceum Teijsm. \& Binn. (80\%), Cymbidium finlaysonianum Lindl. (90\%) and Cymbidium bicolor Lindl. (80\%).

Scade et al. (2006) verified a gradual mortality, over 14 weeks, of six orchid species transplanted to a West Australian bushland. The studies reported survival percentages of 49 and $41 \%$ for Microtis media R.Br. and Diuris corymbosa Lindl., respectively. Caladenia arenicola Hopper \& A.P.Br., Pterostylis sanguinea D.L.Jones \& M.A.Clem. and Disa bracteata Lindl. presented survival rates that varied from $21-23 \%$. Interestingly, a Caladenia flava R.Br. x latifolia R.Br. hybrid exhibited an
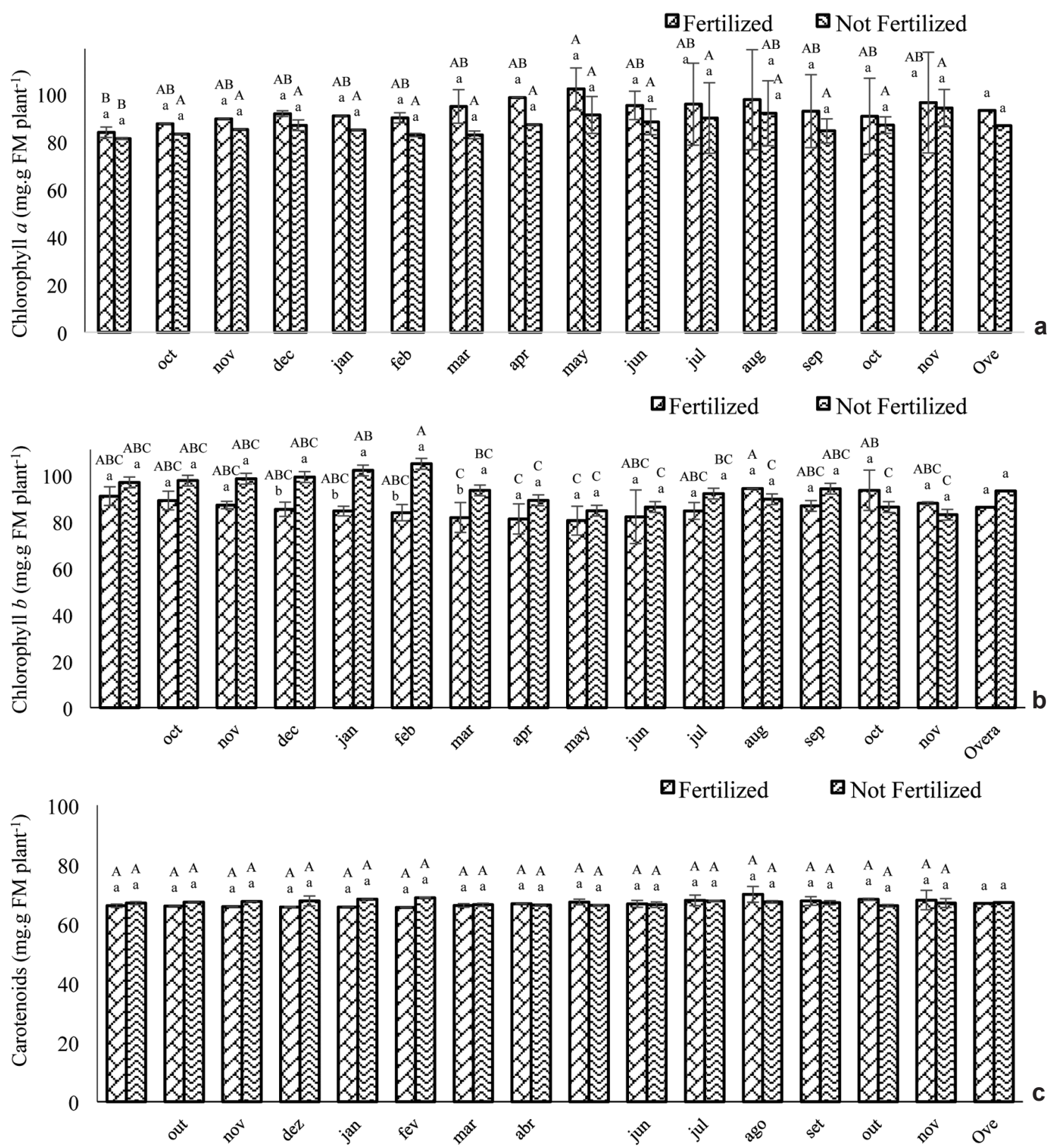

Figure 3 - Monthly values of (a) chlorophyll $a$, (b) chlorophyll $b$ and (c) carotenoids from leaves of Sauroglossum nitidum plants reallocated in the Parque Estadual da Cantareira, São Paulo, Brazil. The mean values with the same letter are not different by the Tukey test. Lower case letters compare fertilized and unfertilized plants each month and upper case letters compare months in each treatment. $\mathrm{n}=50$. 
initially high rate of survival, that rapidly declined thereafter.

Several factors related to the microclimate, such as: relative humidity, water availability in the soil (for terricolous plants), and rainfall have been implicated in the likelihood of survival for reintroduced seedlings (Yam et al. 2010). With regards to rainfall, the drop-in survival tendency observed with fertilized plants in April and August of 2016, could be due to the low amounts of precipitation recorded in April and July of 2016. This observation is consistent with the study of Scade et al. (2006), which showed that one of the causes for the high mortality of reallocated orchids was low precipitation (27\%), and Endres Jr. et al. (2015) observed a causal relationship between the mortality of reallocated Cattleya intermedia Graham plants and reduced rainfall. However, deaths also occurred in during rainy months, thus indicating that the soil water availability is not the only determining factor in $S$. nitidum survival. The high percentage of plant survival in both treatments observed even in months with low rainfall may be related to the species' morpho-anatomy, which has thick roots with $9-10$ cell layers in the canopy and parenchymatic cortex 17-24 cells wide (Moreira \& Isaias 2008), favoring the reduction of loss.
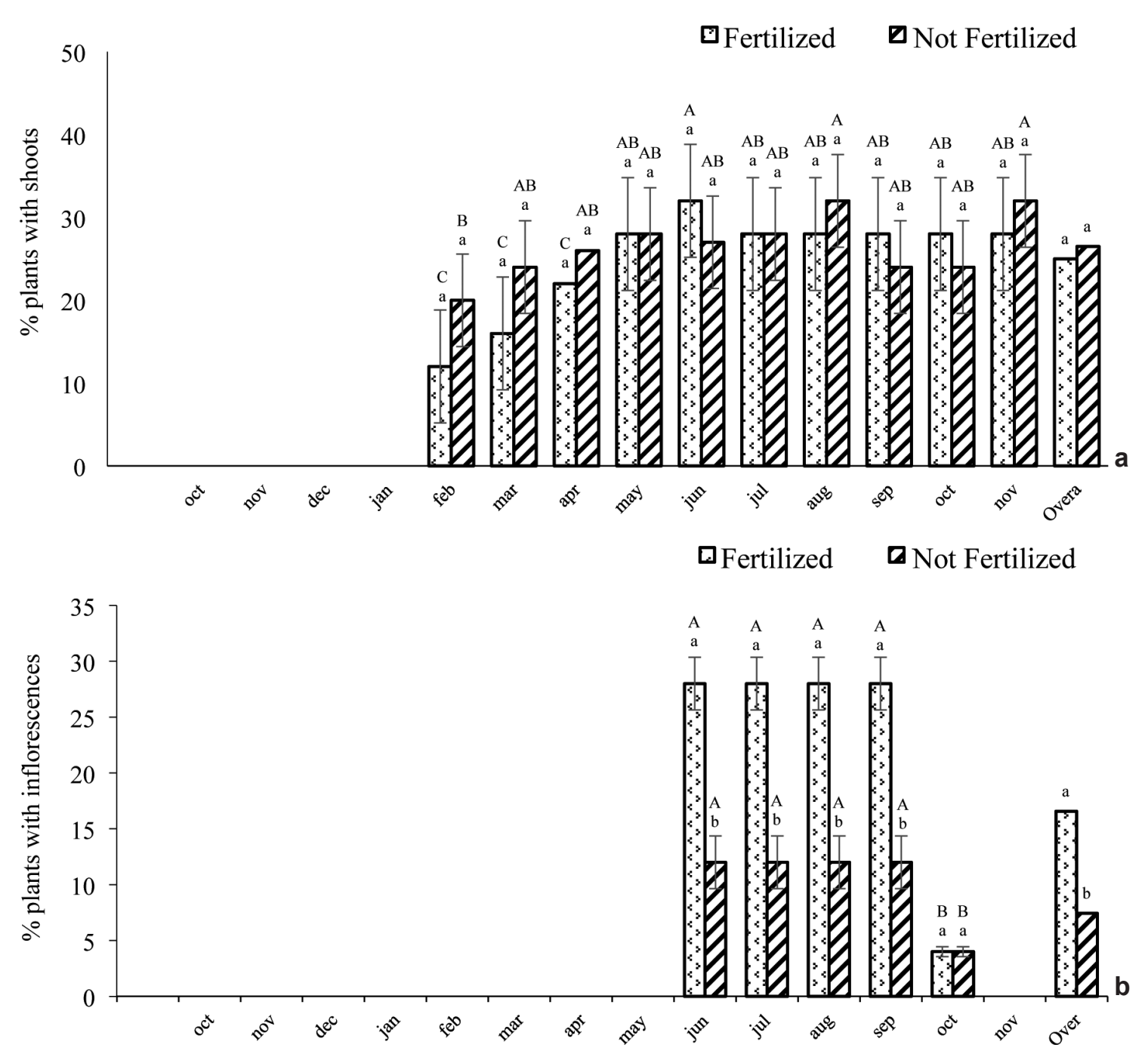

Figure 4 - Monthly percentage values for (a) plants with shoots and (b) plants with inflorescences (floral stem until seed release) for Sauroglossum nitidum plants reallocated in the "Parque Estadual da Cantareira", São Paulo, Brazil. The mean values with the same letter are not different by the Tukey test. Lower case letters compare fertilized and unfertilized plants each month and upper case letters compare months in each treatment. $\mathrm{n}=50$. 
Following reallocation there was a reduction in the number of leaves for both, fertilized and unfertilized plants. It is plausible that this is an adaptive response to the new environment, since there were no reductions in rainfall that could account for changes in water availability. In contrast,
Endres Jr. et al. (2015) observed leaf abscission in C. intermedia following reallocation, possibly due to a water deficit.

A subsequent tendency of increase of the number of leaves was observed in fertilized plants, most likely due to the $\mathrm{N}, \mathrm{P}$ and $\mathrm{K}$ in the fertilizer.
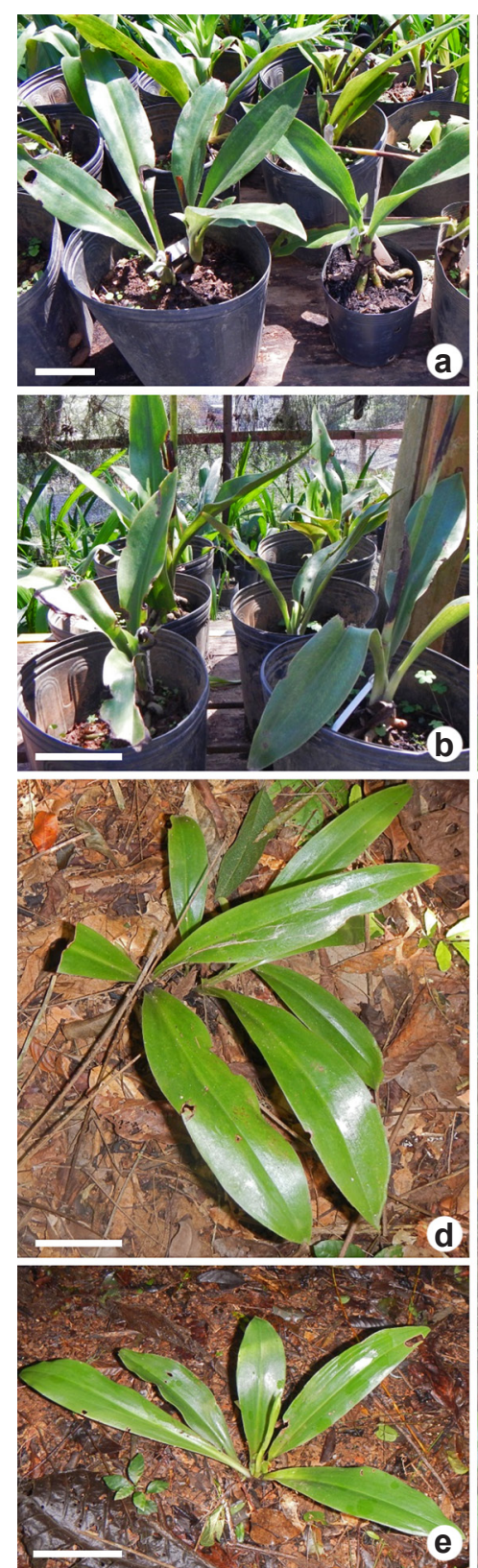
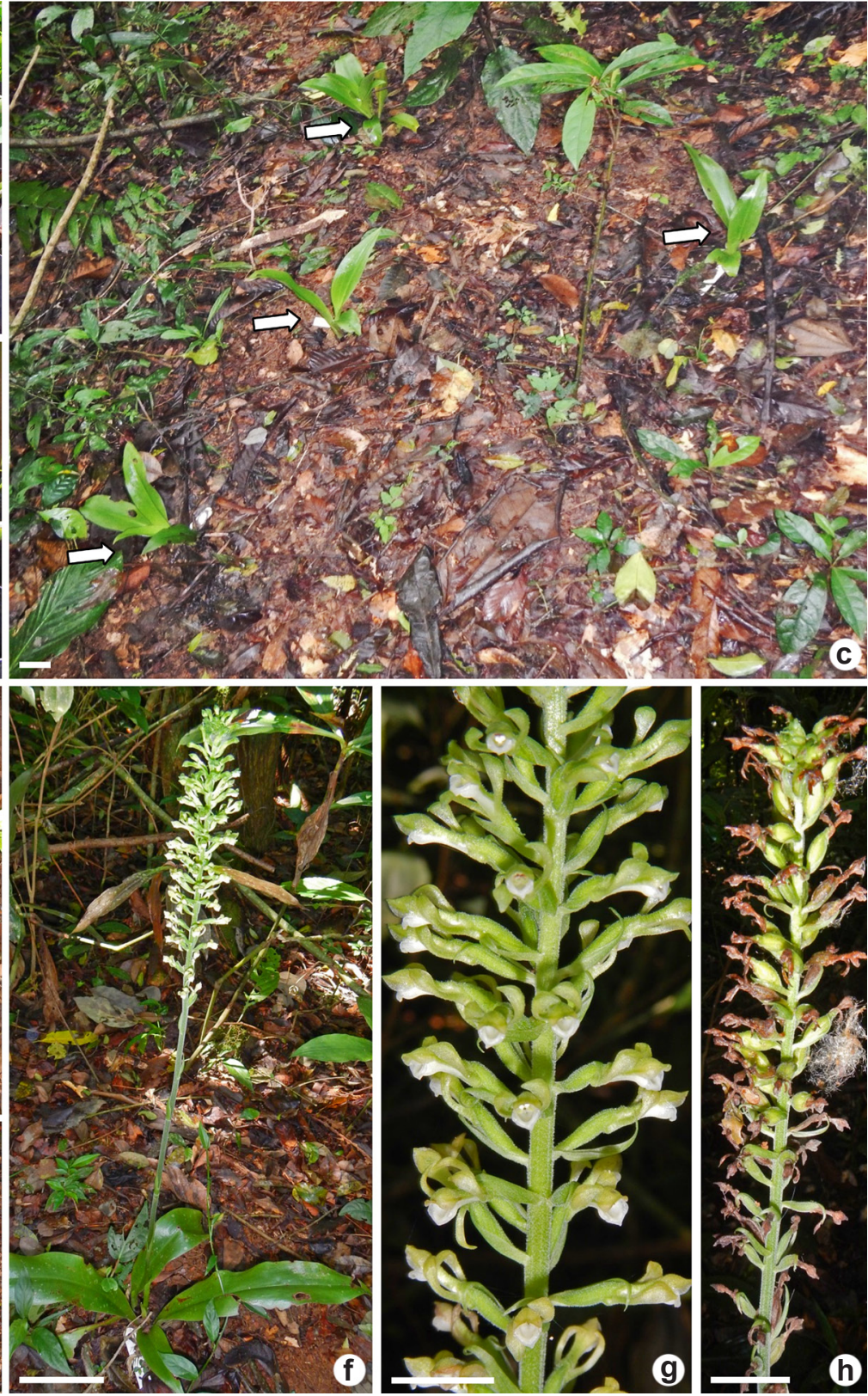

Figure 5 - a-h. Reallocation steps of Sauroglossum nitidum in the Parque Estadual da Cantareira - a-b. plants just before reallocation - a. fertilized; b. not fertilized; c. general picture of the area of transplanted plants after 3 months of relocation (arrows are pointing to the plants of $S$. nitidum); d. plants with lateral bud development; e. initial flower stem development; f. S. nitidum with initial flower stalk; g. detail of the inflorescence; h. fruit formation. Scale bar: $\mathrm{a}, \mathrm{b}, \mathrm{c}, \mathrm{d}, \mathrm{e}, \mathrm{f}=5 \mathrm{~cm} ; \mathrm{g}, \mathrm{h}=2 \mathrm{~cm}$. 
Previous work showed that nitrogen can modulate cytokinins production and cell cycle activation, consequently leading to new leaf formation (Sakakibara et al. 2006). Since nitrogen is required at higher concentrations than phosphorus $(17 \mathrm{x}$ more) (Taiz \& Zeiger 2013), possibly the amount provided in this paper was not sufficient to induce significant difference. Furthermore, it was reported that phosphorus application slightly increased the leaf area in two tree species of orchids, Phoebe zhennan S.K.Lee \& F.N.Wei (Tariq et al. 2017) and Alnus cremastogyne Burkill (Tariq et al. 2018).

The photosynthetic pigment results obtained with $S$. nitidum were unlike those of Tariq et al. (2017), which observed a slight increase in the amount of chlorophyll $a$ in fertilized well-watered $P$. zhennan plants, when compared to unfertilized controls. The amount of chlorophyll $b$ was slightly higher to unfertilized in comparison to fertilized plants. In S. nitidum, even the low concentration of nitrogen supplied in the NPK fertilizer may have contributed to the higher concentration of chlorophyll $a$ in fertilized plants compared to unfertilized ones. This relationship has already been verified in several species (Tamaki et al. 2007; Saleem et al. 2010; Aguerra et al. 2010). Moreover, Tariq et al. (2017) showed that phosphorus fertilization significantly increased the net photosynthetic rate and maximal quantum PSII efficiency of $P$. zhennan under drought stress conditions. The authors attributed enhanced root biomass, decreased malondialdehyde content, and up-regulation production of chloroplast pigments, osmolytes, and nitrogenous compounds to these augmented processes.

The emergence of shoots after six months, and the appearance of flowering after 10 months, provide evidence of effective adaptation by the plants to their new environment. Importantly, the reallocation strategy showed that both fertilized and unfertilized plants, were able to reach to the reproductive phase following reallocation.

The present study demonstrated that NPK fertilization can increase $S$. nitidum flowering. Similarly, Bichsel et al. (2008) observed reduced flowering node numbers and flowers per node, as well as delayed flowering when no phosphorus was applied to Dendrobium nobile Lindl. orchids. Although the fertilizer used was NPK, the concentrations of $\mathrm{N}$ and $\mathrm{K}$ were low compared to P. Phosphorus was also shown to enhance flower formation in Psygmorchis pusilla (L.) Dodson \& Dressler grown in vitro (Vaz \& Kerbauy 2000). In conclusion, it is possible successfully reallocate
S. nitidum plants within preserved environments. Based on the flowering results a successful orchid reallocation was verified, since this is indicative of a functional reproductive cycle. Finally, NPK (1052-10) fertilization appeared to stimulate flowering in this species of orchid.

\section{Acknowledgements}

The authors are grateful to DERSA (Road Development); and the teams that worked on the environmental actions of the highway.

\section{References}

Aguerra E, Purificacon C \& Purificacon H (2010) Induction of leaf senescence by low nitrogen nutrition in sunflower (Helianthus annuus) plants. Physiologia Plantarum 138: 256-267.

Ali MH, Dash PK, Islam MM, Ahmed M \& Mondal T (2014) Effect of NPK spray formulation on growth of two cultivars of orchid (Mokara Sp.). Journal of Agriculture and Veternary Science 7: 31-42.

Bernardi AC, Faria RT, Carvalho JFRP, Unemoto LK \& Assis AM (2004) Desenvolvimento vegetativo de plantas de Dendrobium nobile Lindl. Fertirrigadas com diferentes concentrações da solução nutritiva de sarruge. Semina: Ciências Agrárias 25: 13-20.

Bichsel RG, Starman TW \& Wang YT (2008) Nitrogen, phosphorus, and potassium requirements for optimizing growth and flowering of the nobile Dendrobium as a potted orchid. HortScience 43: 328-332.

Campos DM (1998) Orquídeas: manual prático de cultura. Expressão e Cultura, Rio de Janeiro. 143p.

Cintra M (2014) Os custos dos congestionamentos na cidade de São Paulo. In: Textos para discussão da Escola de Economia de São Paulo da Fundação Getúlio Vargas 356. FGV-EESP, São Paulo. 35p.

Dantas ASL (1990) Geologia da faixa São Roque e intrusivas associadas na região entre São Paulo e Mairiporã, norte de São Paulo - SP. Dissertação de Mestrado. Universidade de São Paulo, São Paulo. $189 \mathrm{p}$.

Dorneles LT \& Trevelin V (2011) Aclimatização e reintrodução de Cattleya intermedia Graham ex Hook (Orchidaceae) obtidas por propagação in vitro. Iheringia Série Botanica 66: 167-174.

Du Y \& Scheres B (2018) Lateral root formation and the multiple roles of auxin. Journal of Experimental Botany 69: 155-167.

Endres Júnior D, Sasamori MH, Hisayuki M, Schmitt JL, Lizandro J \& Droste A (2018) Survival and development of reintroduced Cattleya intermedia plants related to abiotic factors and herbivory at the edge and in the interior of a forest fragment in South Brazil. Acta Botanica Brasilica 32: 555-556. 
Endres Júnior D, Sasamori MH, Silveira T, Schmitt JL \& Droste A (2015) Reintrodução de Cattleya intermedia Graham (Orchidaceae) em borda e interior de um fragmento de Floresta Estacional Semidecidual no sul do Brasil. Revista Brasileira de Biociências 13: 33-40.

Jasper A, Freitas EM, Musskopf EL \& Bruxel J (2005) Metodologia de salvamento de Bromeliaceae, Cactaceae e Orchidaceae na Pequena Central Hidrelétrica $(\mathrm{PCH})$ Salto Forqueta - São José do Herval/ Putinga, RS, Brasil. Pesquisas Botânicas 56: 265-284.

Koppen W \& Geiger R (1928) Klimate der Erde. Justus Perthes Verlag, Gotha. Wall map.

Lichtenthaler HK (1987) Cholorophylls and carotenoids: pigments of photosynthetic biomembranes. In: Packer L \& Douce R (eds.) Methods in enzymology. Academic Press, London. Pp. 350-382.

López-Bucio J, Cruz-Ramírez A \& Herrera-Estrella L (2003) The role of nutrient availability in regulating root architecture. Current Opinion in Plant Biology 6: 280-287.

Monda T, Dash PK, Ahmed M, Islam MM \& Ali MH (2014) Growth performance of orchid (Dendrobium Sp.) as influenced by different npk spray concentration. International Journal of Biosciences 4: 15-27.

Markwell J, Osterman JC \& Michell JL (1995) Calibration of the Minolta SPAD-502 leaf chlorophyll meter. Photosynthesis Research 46: 467-472.

Moreira ASFP \& Isaias RMS (2008) Comparative anatomy of the absorption roots of terrestrial and epiphytic orchids. Brazilian Archives of Biology and Technology 51: 83-93.

Munné-Bosch S \& Lalueza P (2007) Age-related changes in oxidative stress markers and abscisic acid levels in a drought-tolerant shrub, Cistus clusii grown under Mediterranean field conditions. Planta 225:10391049.

Romanini R \& Barros F (2007) Flora fanerogâmica da Ilha do Cardoso Orchidaceae. In: Melo MMRF, Barros F, Chiea SAC, Kirizawa M, Jung-Mendaçolli SL \& Wanderley MGL (eds.) Flora fanerogâmica da Ilha do Cardoso. Instituto de Botânica/Secretaria do Meio Ambiente, São Paulo. Pp. 29-275.

Sakakibara H, Takei K \& Hirose N (2006) Interactions between nitrogen and cytokinin in the regulation of metabolism and development. Trends in Plant Science 11: 440-448.

Saleem MF, Ma BL, Voldeng H \& Wang TC (2010) Nitrogen nutrition on leaf chlorophyll, canopy reflectance, grain protein and grain yield of wheat varieties with contrasting grain protein concentration. Journal or Plant Nutrition 33: 1681-1695.

São Paulo (2009) Plano de Manejo do Parque Estadual da Cantareira. Fundação Florestal, São Paulo. 586p.

Scade A, Brundrett MC, Batty AL, Dixon KW \& Sivasithamparam K (2006) Survival of transplanted terrestrial orchid seedlings in urban bushland habitats with high or low weed cover. Australian Journal of Botany 54: 383-389.

Seeni S \& Latha PG (2000) In vitro multiplication and eco-rehabilitation of the endangered Blue Vanda. Plant Cell, Tissue and Organ Culture 61: 1-8.

Suzuki RM, Moreira VC, Pescador R \& Ferreira WM (2012) Asymbiotic seed germination and in vitro seedling development of the threatened orchid Hoffmannseggella cinnabarina. In Vitro Cellular \& Developmental Biology Plant 48: 500-511.

Taiz L \& Zeiger E (2013) Fisiologia vegetal. $5^{\text {th }}$ ed. Artmed, Porto Alegre. 920p.

Tamaki V, Mercier H \& Nievola CC (2007) In vitro culture of clones Ananas comosus (L.) MerrillSmooth Cayenne in different concentrations of macronutrients. Hoehnea 34: 67-73.

Tariq A, Pan K, Olatunji OA, Graciano C, Li Z, Sun F, Sun X, Song D, Chen W \& Zhang A (2017) Phosphorous application improves drought tolerance of Phoebe zhennan. Front Plant Science 8: 1561.

Tariq A, Pan K, Olatunji OA, Graciano C, Li Z, Sun F, Sun X, Song D, Chen W, Zhang A, Wu X, Zhang L, Mingrui D, Xiong Q \& Huang D (2018) Phosphorous fertilization alleviates drought effects on Alnus cremastogyne by regulating its antioxidant and osmotic potential. Scientific reports 8: 1-11.

Vaz APA \& Kerbauy GB (2000) Effects of mineral nutrients on in vitro growth and flower formation of Psygmorchis pusilla (ORCHIDACEAE). Acta Horticulturae 520: 49-156.

Yam TW, Chua J, Tay F \& Ang P (2010) Conservation of the native orchids through seedling culture and reintroduction - a Singapore experience. The Botanical Review 76: 263-274. 